\title{
АССИГНАЦИЯ И БИЛЕТ В СИСТЕМЕ НОМИНАЦИЙ ДЕНЕЖНЫХ ЗНАКОВ ВОСТОЧНОСЛАВЯНСКОГО ЯЗЫКОВОГО ПРОСТРАНСТВА
}

\author{
T. В. ОХРІМЕНКО. АСИГНАЦІЯ ТА БІЛЕТ У СИСТЕМІ НОМІНАЦІЙ ГРОШОВИХ \\ ЗНАКІВ СХІДНОСЛОВ'ЯНСЬКОГО МОВНОГО ПРОСТОРУ. \\ У статті подано аналіз одних із найуживаніших в украӥнській, російській та білорусь-
} кій мовах XIX - XX cm. грошових номінацій із опорними словами 'знак', 'білет' та 'асигнація', які зафіксовано у східнослов'янській лексикографії та друкованих чи авторських нумізматичних каталогах. Слов'янський традииійний науковий дискурс характеризує визначення грошей як 'грошових знаків', 'металевих та паперових знаків', 'знаків вартості', 'знаків готівкової оплати', 'знаків золота'. Долучення грочей до категорій умовних знаків виглядає мотивованим як із позицій соиіально-економічних (особливо в умовах сучасного суспільства, яке відійшло від натурального обміну, золотого стандарту та підійшло до девальвації иіни грошової одинииі), так $i$ з позицій філософських (умовний грошовий знак заміщує реальну вартість товару та стає матеріальним представником певної абстрактної цінності). Знаковою можна назвати будь-яку матеріалізовану форму товарно-грошових відносин як частини глобальних суспільних відносин. На території, де мешкають східні слов'яни, 'кредитний / банківський білет' (окрім нерозмінюваного 'казначейського') був і залишається державним знаком вартості та оплати, офіційним грошовим знаком, який має традиційний номінал у рублях чи карбованиях, приймається як оплата по всій державі та обмінюється на дорогоцінний метал. Його синонім 'асигнаиія' використовувався в російській, українській та білоруській мовах для визначення грошових сум, особливо великого номіналу, але не включався в офіційну назву грошей та не друкувався на купюрах. 'Білетом' (іноді 'асигновкою') називали й негрошові знаки (свідоцтва, документи на право володіння, вхідні талони, чеки підприємств) або громові сурогати (білети громоворечової лотереї, рос. 'сберегательные билеть').

Ключові слова: грошовий знак, грошовий сурогат, асигнація, білет.

T.В. ОХРИМЕНКО. АССИГНАЦИЯ И БИЛЕТ В СИСТЕМЕ НОМИНАЦИЙ ДЕНЕЖНЫХ ЗНАКОВ ВОСТОЧНОСЛАВЯНСКОГО ЯЗЫКОВОГО ПРОСТРАНСТВА.

В статье анализируются одни из наиболее употребительных в украинском, русском и белорусском языках XIX - XX вв. денежных номинаций с опорными словами 'знак', 'билет' и 'ассигнация', которые зафиксированы в восточнославянской лексикографии и печатных или авторских нумизматических каталогах. Славянский традиционный научный дискурс характеризует определение денег в качестве 'денежных знаков', 'металлических и бумажных знаков', 'знаков стоимости', 'знаков наличной оплаты', 'знаков золота'. Рассмотрение денег среди категорий условных знаков представляется мотивированным как с сочиально-экономической точки зрения (особенно в условиях современного общества, отошедшего от натурального обмена, золотого стандарта и пришедшего к девальвачии цены денежной единицы), так и с философской точки зрения (условный денежный знак замещяает реальную стоимость товара и является материальным представителем некой абстрактной ценности). Знаковой можно назвать всякую материализированную форму товарно-денежных отношений как части глобальных общественных отношений. На территории проживания восточных славян 'кредитный / банковский билет' (кроме неразменного 'казначейского') был и остаётся государственным знаком стоимости и оплаты, официальным денежным знаком, имеющим традиционный номинал в рублях или карбованцах, принимаемым в качестве оплаты по всей стране и обмениваемым на драгоценный металл. Его синоним 'ассигнация' использовался в русском, украинском и белорусском языках для обозначения денежных сумм, особенно большого достоинства, но не включался в офичиальное название денег и не печатался на купюре. 'Билетом' (иногда 'ассигновкой') называли и неденежные знаки (свидетельства, документы на

(C) Т.В. Охрименко, 2019

https://doi.org/10.34142/2312-1572.2019.01.67.03 
право владения, входные талоны, чеки предприятий) или денежные суррогаты (билеты денежно-вещевой лотереи, сберегательные билеты).

Ключевые слова: денежный знак, денежный суррогат, ассигначия, билет.

\section{T. V. OKHRIMENKO. ASSIGNATION AND TICKETS IN THE SYSTEM OF NOMINATIONS FOR MONEY OF THE EAST SLAVIC LANGUAGE SPACE.}

The article deals with the most used in the Ukrainian, Russian and Belarusian languages of the XIX - XX centuries. the names of money with the main words 'sign', 'ticket' and 'assignation'. These names are recorded in East Slavic lexicography and printed or authored numismatic catalogs. Slavic traditional scientific discourse is characterized by the definition of money: 'money signs', 'metal and paper marks', 'signs of value', 'signs of cash payment', 'golden signs'. Money really belongs to the categories of conventional signs. This is understandable from the socio-economic point, because in modern society we observe a departure from natural exchange, the gold standard and the approach to devaluation of the price of a monetary unit. From the philosophical standpoint, the conventional monetary sign replaces the real value of the goods and becomes the material representative of a certain abstract value. Significance can be called any materialized form of commodity-money relations as part of global social relations. 'Credit / Banking ticket' (other than unrecoverable 'Treasury ticket') has been and remains the official sign of value and payment in the territory where the eastern Slavs live, an official monetary sign. He had a traditional denomination in rubles or karbovanets, accepted as payment throughout the state and exchanged for precious metal. His synonym for 'assignation' was used in Russian, Ukrainian and Belarusian to identify large amounts of money, but was not included in the official name of the money and was not printed on banknotes. Noncash signs (certificates, documents for the right of possession, entrance vouchers, checks of enterpri?es) or money surrogates (tickets of money-lottery, 'savings tickets') were also called 'Ticket' (also 'asyhnovka').

Key words: money sign, money surrogate, assignation, ticket.

Формирование системы номинаций денежных знаков в качестве объективного свидетельства социальных, экономических, политических, эстетических и психологических изменений в жизни общества интересует учёных из разных областей знания. Так, историками и нумизматами изучаются легенды и девизы на монетах и купюрах, ученые-гуманитарии исследуют денежные средства с культурно-познавательной целью.

Интересно, что в СССР в условиях плановой, нерыночной экономики при общем отрицании понятий денежного рынка и денежного капитала коллекционеры накапливали нумизматический капитал, привезённый из Советского Союза, о чём свидетельствуют многочисленные каталоги монет советского и досоветского периодов, а также труды экономистов и коллекционеров-нумизматов, в частности, восточнославянских исследователей XX - XXI вв. (В. В. Зварич, Р. М. Шуст, П. Ф. Рябченко, М. И. Котляр, В. А. Ющенко, В. С. Стельмах, В. Д. Гладкий, А. С. Люлько, А. П. Орлов, В. М. Копорулина, Л. И. Мачулин, Ю. В. Сфименко, А. А. Щелоков, М. С. Барышников и др.). История формирования названий денежных единиц становится предметом особого изучения этимологов русского, украинского и белорусского языков, начиная с периода XIX в. (И. И. Толстой, Е. И. Чернов, Н. Г. Рядченко, М. Ф. Дмитриенко, Р. И. Тхоржевский, А. Д. Огуй, И. Н. Колобова и др.).

Однако до сих пор не существует полного объяснительного каталога и словаря денежных номинаций, функционировавших на славянских землях, ещё уточняется ряд названий металлических и бумажных денег - утерянных, забытых или скрытых. Целью данного исследования является изучение употребительных в XIX - XX вв. названий денежных номинаций с опорными словами денежный знак, билет и ассигнация, оставивших след в восточнославянской лексикографии и нумизматических каталогах.

Определение денег в качестве денежных знаков, металлических и бумажных знаков, знаков стоимости, знаков (наличной) оплаты, знаков золота характеризует славянскую энциклопедическую науку, что можно наблюдать, например, при толковании понятия деньги в современных экономических словарях: 'металлические и / или бумажные знаки, являющиеся мерой стоимости при купле-продаже и выполняющие роль всеобщего эквивалента, то есть выражающие стоимость всех других товаров и обмениваемые на любой из них' [2, с. 216]; 'економічна категорія, що означає специфічний універсальний товар, який є еквівалентом вартості 
інших товарів, виконує ряд суспільно-економічних функцій та представлений у готівковому обігу у вигляді грошових знаків (паперових банкнот, монет, казначейських білетів)' $[5$, с. 76$]$.

Рассмотрение денег в качестве условных знаков (особенно в современном обществе, отошедшем от натурального обмена и золотого стандарта) представляется мотивированным с философской точки зрения, так как знак принадлежит к сложным структурным образованиям и может быть всякой вещью, выполняющей функцию указывать на нечто иное, а не демонстрировать самоё себя [8, с. 70], то есть условный денежный знак может замещать реальную стоимость товара или быть представителем некой материальной ценности, например, золота. Известно, что знаки имеют двойную природу - материальную (с планом выражения, формой, доступной для восприятия) и идеальную (со скрытым планом содержания, тайным смыслом) [10, c. 171].

Ведущий теоретик в области товарно-денежных механизмов Карл Маркс в известном труде «Капитал» отмечал, что «денежная форма вещи в сравнении с самой вещью внешняя и представляет собой лишь форму скрытых за нею человеческих отношений. ...В таком понимании каждый товар является знаком, ведь с точки зрения стоимости он - только вещественная оболочка потраченого на него человеческого труда» [7, с. 50]. По-видимому, знаковой можно назвать всякую овеществлённую, материализированную форму товарно-денежных отношений как части глобальных социально-экономических отношений.

В «Толковом словаре живого великорусского языка» В. И. Даля собирательное существительное деньги, образованное от названия устаревшей монеты де́н определению денег как металлических и бумажных знаков: 'капитал, наличное, ходячая монета всякого рода, звонкая и бумажная' [3, с. 709], монета - 'звонкий денежный знак, де́ньга, ходячая (или ходившая) чеканенная ценность... и всякий денежный знак’ $[4$, с. 570]; ассигновка, ассигнация - 'бумажный денежный знак, взамен и для размена на звонкую монету, кредитный билет ... упал в цене против звонкой монеты'; ассигновать - 'назначать, определять, разрешать к отпуску и приёму деньги, вещи' [3, с. 43]. Известно, что до середины XIX в. ассигнации в дореволюционном значении этого слова не просто снизились в цене, но и были полностью аннулированы. Тем ценнее представляются энциклопедические сведения, собранные в словарных статьях В. И. Даля.

Если знак этимологически связан с глаголом 'знати' (др.-рус., ст.-слав. знакъ, укр., блр. знак, производн. от основы гл. *znati (рус. знать); сюда же знакомый, значит, значить, значиться, обозначить, значение [11, с. 280]), то ассигнация для славянских языков - заимствованное слово. Ассигновать (от лат. assignāre 'назначать, выделять') - 'выделить определённые денежные средства на какие-н. расходы, для каких-н. целей (спец.)', 'назначить выдачу денег', н., ассигновать деньги на капитальное строительство; ассигнация - 'бумажный денежный знак в России (с 1769 по 1849 г.)'; ассигнование - кроме процесса, связанного с 'ассигнацией', имеет значение 'ассигнованная сумма', н., большие ассигнования [11, с. 22]. Ассигновка - 'документ строго определённой формы, на основании которого учреждения, занимавшиеся кассовым исполнением государственного и местных бюджетов, выдавали средства на расходы, предусмотренные бюджетом' [2, с. 54]. В отличие от устаревшего русифицированного слова ж. p. ассигновка, иноязычный термин ассигнация до сих пор используется как международное обозначение 'бумажных денег-банкнот' [2, с. 54].

Анализ опубликованного в XX в. нумизматического материала [6; 9] и материала авторских коллекций показывает, что ассигновка, ассигнация не были включены в официальное название денежных единиц на территории проживания восточных славян, хотя о них говорится в энциклопедической литературе, например: Першымі папяровымі гр. на уссх. Беларусі былі рас. асігнаџьы уззору 1769, у зах. - асігнащъыі 1794 урада Т. Касиюшкі [1, с. 251].

Билет, упомянутый в Словаре В. И. Даля в качестве синонима ассигновки, ассигнации, был опорным словом на денежных знаках восточных славян. Это также заимствованное слово (от фp. billet 'записка, билет'), которое в славянских языках имело основным значением 'документ, удостоверяющий право пользования чем-нибудь, посещения чего-либо за плату’, однако среди иных значений включало и 'бумажный денежный знак', н., билет государственного банка; кредитный билет (то же, что банковский билет); казначейский билет [11, с. 44; 2, с. 99].

Действительно, билет в качестве денежной единицы в русской специализированной терминологии включает ряд номинаций, подтверждающих примеры толкового словаря русского языка: 1) банковский билет - платёжное средство, выпускаемое банком и имеющее широкую область распространения, а также разновидность денежных знаков, выпускаемых в обра- 
щение центральными банками; 2) казначейский билет - вид неразменных бумажных денег, которые выпускались правительственными органами (казначействами) и не подлежали обмену на драгоценные металлы, а также краткосрочные обязательства государства, находящиеся в обращении (это были скорее денежные суррогаты, так как не представляли реальной ценности и не менялись на драгоценные металлы - О.Т.); 3) кредитный билет - знаки стоимости, выпускаемые эмиссионными банками, а также отождествляемые с банковскими билетами; 4) рублевой билет в России - бумажная денежная купюра достоинством в один рубль, изъятая из обращения во время денежной реформы 1991 г. [2, с. 99]. Как документы или свидетельства, подтверждающие право на владение чем-либо, на оплату чего-либо, но не как самодостаточные денежные знаки, известны: входной билет для платного одноразового прохода куда-либо; лотерейный билет с правом выигрыша в лотерее; ломбардный билет, выдаваемый ломбардами владельцу вещи при получении им ссуды; лесорубный билет для получения древесины [2, с. 99]; сберегательный билет, подтверждающий банковский вклад - т.е. денежные средства, внесённые для хранения в банки, сбербанки на определённых условиях [2, с. 150].

На основе анализа нумизматического материала можно отметить важную роль на восточнославянском денежном рынке номинации государственный кредитный билет (помним, что его синоним - 'банковский билет', 'билет центрального банка'), который был денежной единицей XIX - н. XX вв. с номиналом в рублях, о чём была соответствующая надпись на купюре (подобно рублевому билету России к. XX в.). На царских бумажных деньгах на лицевой стороне под надписью «Государственный кредитный билеть» и достоинством «Одинь рубль»

(или иным номиналом) было напечатано: «Государственный банкъ размђниваетъ кредитные билеты на золотую монету безъ ограничені1а суммы (1 рубль=1/15 имперіала), содержить 17 , 424 долей чистаго золота)». Империал - это устаревшее название ценной российской золотой монеты 11,61 г чистого золота 1755-1899 гг. выпуска с номиналом в 10, 15 рублях [2, с. 348], с которой сравнивались последующие денежные знаки в Российской империи, однако с дальнейшим уменьшением доли золота в монетах и соответствующих купюрах. На оборотной стороне кредитного билета читаем: «1. Размћнъ государственныхъ кредитныхъ билетовъ на золотую монету обезпечивается всБмъ достояніемъ государства. 2. Государственные кредитные билеты имьютъ хожденіе во всей имперіи наравнь съ золотою монетою (вспомним о значении денег у В. И. Даля как 'ходячей монеты всякого рода, звонкой и бумажной'; ходячая монета т.е. не инвестиционная и не коллекционная, обслуживающая широкое денежное обращение, или хождение, - О.Т.). 3. За поддБлку кредитныхъ билетовъ виновные подвергаются лишенію всБхъ правъ состоянія и ссылкち въ каторжную работу».

Первые банкноты украинского самостоятельного государства н. ХХ в. (УНР) также назывались билеты, которые были эмитированы (выпущены в обращение) в 1918 г. под. названим державні кредитові білети достоинством 100 карбованців и стоимостью, которая равнялась 17, 424 доле чистого золота (1 доля $=0,044$ г золота). Фактически эти деньги стремились приблизиться к ценности царского золотого империала.

После 1917 г. выпускались билеты государственного казначейства «главнаго командовані1а вооруженными силами на югђ Россіи» (южных регионов Украины и Крыма при правительстве Деникина - О.Т.) с указанием на принадлежность данных купюр всем государственным денежным знакам, в том числе ещё не выпущенным в оборот, что в свете официального денежного обращения выглядит неправдоподобным и не заслуживающим доверия (вспомним определение казначейского билета как неразменных бумажных денег, которые не менялись на драгоценные металлы): «Билеты Государственнаго Казначейства подлежатъ обмьну на денежные знаки, имђющіє быть выпущенными Единымъ Россійскимъ Правительствомъ».

Во время Первой мировой войны в Росийской империи не хватало металла и денег, поэтому вместо металлических денег вводились временные денежные знаки, например, бумажные мелкие деньги в 50 коп Бекъ, на которых была надпись о соответствии серебряным, а не золотым монетам: «имђютъ хожденіе наравнђ съ размћнной серебряной монетой». Однако на оборотной стороне купюры указывалась принадлежность этого малоценного денежного знака не суррогатам, а традиционному названию ценной денежной единицы к. XIX - н. XX ст. билетъ, что можно рассматривать либо в качестве официального обмана населения с помощью 
фальшивых государственных денег, либо с точки зрения расширения семантического поля лексемы билет: «Поддьлка билета пресльдуется закономъ».

В период Второй мировой войны выпускался государственный казначейский билет $\boldsymbol{C C C P}$ с номиналом в рублях, переводом на языки Советского Союза и соответствующей военной тематикой рисунка. Это были денежные знаки малой ценности, так как принадлежали неразменным казначейским билетам.

В качестве примера билета как документа или свидетельства на право владения чемлибо, на оплату чего-либо, близкого денежному знаку, можно привести пример білету грошово-речової лотереї (некоего суррогата лотерейного билета и денежного знака периода вт. пол. XX в.) с подписью эмитента не государственного банка, а министерства финансов УССР с отметкой «Госзнак», с надписью «вартість білета 50 копійок», с праздничным поздравлением, например, «Вітаємо з святом 8 березня!», с указаним того, когда произойдёт розыгрыш билетов, и примечанием, похожим на надписи денежных знаков, однако в сослагательном наклонении, что было недопустимо на официальных знаках стоимости: «власник лотерейного білета, на який припав виграш, може за бажанням одержати взамін речового виграшу його вартість готівкою».

К тому же историческому периоду относятся квитанции-пожертвования (часто принудительного характера оплаты) под названием благодійні білети радянського дитячого фонду iмені В. І. Леніна. Эти билеты имели привычный номинал в рублях и традиционную советскую помету всех знаков оплаты «Госзнак». Особенностью такого билета, не принадлежащего официальным денежным знакам, следует назвать вольную стилистику обширного сопроводительного текста с обилием риторических фигур и тропеических средств. Вначале, на лицевой стороне, прочитывается письменная благодарность с конструкцией уважительного обращения: Спасибо вам за ваш взнос в строительство городка семейного детского дома. Затем, на оборотной стороне, объясняется «необычное» назначение данного билета, также представленное в форме уважительно-дружественного обращения к покупателю с использованием стилистических средств (многочисленных эпитетов, уточнений, приложений, повторов, гипербол, уменьшительно-ласкательных слов, абстрактных имён существительных высокого стиля речи, вставных конструкций и выделительных знаков препинания): Дорогой друг! Деньги, заплаченные Вами за этот необычный билет, пойдут не просто на строительство. Городок семейного детского дома станет надежным и - что самое главное - истинно домашним кровом для тех, кто лишился его в силу трудных жизненных обстоятельств. Сделав свой вклад в строительство этого дома, в этот маленький город, и Вы стали его строителем. А значит созидателем добра и человеческой мудрости, хранителем домамнего очага для маленьких сирот, для детей, обездоленных родительским теплом.

Название собственно денежных единиц билеты государственного банка использовалось не только в СССР (с традиционным синонимом банковские билеты, например, в 1991 г.: «Банковские билеты обеспечиваются золотом, драгоценными металлами и прочими активами государственного банка»). Подобное название до сих пор сохраняется в РФ и в Беларуси. Так, в 1992 г. в Беларуси были напечатаны бумажные рассчётные билеты - разліковыя білеты с эмитентом Национальным банком Республики Беларусь, которые были в обращении до 1993 г. С июля 1992 г. денежные системы Беларуси и России разделились, в результате чего возник безнаяуины бел. рубель. В 1994 г. белорусскому рублю и рассчётному билету (бел. разліковаму рубелю) присвоен статус единого платёжного средства Республики Беларусь [1, с. 251], в то время как в Украине национальной валютой признана гривня без статуса 'билета', но с указанием эмитента - Национального банка Украины. На купюрах рублей РФ напечатано билет банка России с традиционным предупреждением при упоминании номинации билет: «подделка билетов банка России преследуется по закону».

Таким образом, в результате анализа денежных номинаций восточнославянского языкового пространства последних двух столетий можно прийти к выводу, что опорным словом одного из наиболее характерных названий денежных знаков был билет как государственный знак стоимости и оплаты, имеющий традиционный номинал в рублях, принимаемый по всей стране и обмениваемый на драгоценный металл. Его синоним ассигнация использовался в языке для обозначения денежных сумм, особенно большого достоинства, но не включался в официальное название денег и не печатался на купюре. Билетом называли и неденежные знаки (свидетельства, документы на право владения, входные талоны и т.д.) или денежные суррогаты (например, билеты денежно-вещевой лотереи). 
Перспективным представляется исследование лексико-грамматических средств создания номинаций всех известных видов дензнаков XX в. как названий денежных единиц временного или ограниченного употребления.

\section{ЛИТЕРАТУРА}

1. Беларусь: Энцыклапедычны даведнік / Беларуская энцыклапедыя; Рэд. калегія: Б. І. Сачанка (гал. рэд.) і інш. Мн.: «Беларуская энцыклапедыя», 1995. 800 с.

2. Большой экономический словарь / Под ред. А. Н. Азрилияна. 7-е изд., доп. М.: Институт новой экономики, 2007. 1472 с.

3. Даль В. И. Толковый словарь живого великорусского языка: Современное написание: В 4 т. / В. И. Даль. Т. 1. А - 3. М.: ООО «Издательство АСТ»: ООО «Издательство Астрель», 2003. $1158 \mathrm{c}$.

4. Даль В. И. Толковый словарь живого великорусского языка: Современное написание: В 4 тт. Т. 2. И - О. М.: ООО «Издательство АСТ»: ООО «Издательство Астрель», 2003. $1280 \mathrm{c}$.

5. Економічний термінологічний словник-довідник: економіка, фінанси, менеджмент / За заг. ред. С. А. Корнієнка і В. Я. Олійника. Дн.: Дніпропетр. держ. фін. академія, 2013. 460 с.

6. Зварич В. В. Нумизматический словарь. Изд-е 2-е / Автор-составитель В. В. Зварич; отв. ред. Н. Ф. Котляр. Л.: «Вища школа», 1975. 156 с.

7. Маркс К. Капітал. Критика політичної економії / Упорядкував Ф. Енгельс / Переклад з 4-го нім. видання за ред. Д. Рабіновича і С. Трикоза. У 4 тт. Т. 1. Кн. 1. Процес продукції капіталу. Харків: Партвидав «Пролетар», 1933. 950 с.

8. Петрушенко В.Л. Тлумачний словник основних філософських термінів / В. Л. Петрушенко. Львів: Вид-во нац. ун-ту «Львівська політехніка», 2009. 264 с.

9. Рябченко П. Ф. Полный каталог бумажных денежных знаков и бон России, СССР, стран СНГ (1769-1994 гг.) / Под ред. докт. экон. наук, проф. М. И. Савлука и докт. ист. наук, проф. М. Ф. Дмитриенко. Изд-е 2-е, перераб. и доп. К.: Издательско-культурологический центр «Софія», «Лісбанк», 1995. 670 с.

10. Словарь философских терминов / Под ред. В. Г. Кузнецова. М.: ИНФРА-М, 2005. 731 с. (Библиотека словарей «ИНФРА-М»).

11. Толковый словарь русского языка с включением сведений о происхождении слов / РАН. Институт русского языка им. В.В.Виноградова. Отв. ред. Н. Ю. Шведова. М.: Издательский центр «Азбуковник», 20111175 с.

(Статья поступила в редакичию 28 марта 2019 г.) 